\title{
Effects of Peripartum Propylene Glycol or Fats Differing in Fatty Acid Profiles on Feed Intake, Production, and Plasma Metabolites in Dairy Cows
}

\author{
U. Moallem,${ }^{* 1}$ M. Katz, ${ }^{\star} \dagger$ A. Arieli, $\dagger$ and H. Lehrer* \\ *Department of Dairy Cattle, Institute of Animal Sciences, Volcani Center, P.O. Box 6, Bet-Dagan, 50250 Israel \\ †Department of Animal Science, Faculty of Agriculture, Hebrew University, Rehovot, 76-100, Israel
}

\section{ABSTRACT}

Dry multiparous cows were used to investigate the effects on intake, production, and metabolism of either a supplement containing 55\% dry propylene glycol (PGLY), a prilled fat supplement (PrFA) containing a low proportion of unsaturated fatty acids (FA), or calcium soaps of FA supplement (CaLFA) containing a high proportion of unsaturated FA. Fifty-three dry cows (256 d pregnant) were stratified into 4 groups and began one of the following dietary treatments: 1) control cows were fed a dry cow diet and at postpartum were fed a lactating cow diet; 2) diets of cows in the PGLY group were supplemented with $500 \mathrm{~g} / \mathrm{d}$ per cow of dry PGLY until $21 \mathrm{~d}$ in milk (DIM); 3) diets of cows in the PrFA group were supplemented with 230 g/d per cow of PrFA until 100 DIM; 4) diets of cows in the CaLFA group were supplemented with $215 \mathrm{~g} / \mathrm{d}$ per cow of CaLFA until 100 DIM. Prepartum DMI was lower in the PrFA and CaLFA groups than in the control and PGLY groups, whereas postpartum DMI in the PrFA group was higher than that in the control group. Milk production until 100 DIM in both fat-supplemented groups was $4.5 \%$ higher than that in the control group. Plasma glucose concentrations pre- and postpartum were higher in the PGLY group than in the PrFA and CaLFA groups, but were similar to those in the control group. Prepartum nonesterified FA (NEFA) concentrations in plasma were increased by 43 and $70 \%$ in the PrFA and CaLFA groups, respectively, as compared with the control and PGLY groups. Both fat supplements increased plasma $\beta$-hydroxybutyrate concentrations over those of the PGLY and control groups pre- and postpartum. Peripartum plasma insulin concentrations in the control group were 1.7-fold higher than in the PrFA group and 2.1-fold higher than in the CaFA group. Differences between the PrFA and CaLFA groups were observed: DMI was

Received February 8, 2007.

Accepted April 21, 2007.

${ }^{1}$ Corresponding author: uzim@volcani.agri.gov.il higher pre- and postpartum in the PrFA group than in the CaLFA group, and prepartum plasma NEFA concentrations were $19 \%$ higher and insulin concentrations were $21 \%$ lower in the CaLFA group than in the PrFA group. No significant differences were observed in DMI, plasma glucose, NEFA, and $\beta$-hydroxybutyrate concentrations between the control and PGLY groups. Feeding fat to cows during late pregnancy decreased the DMI and negatively affected the metabolic status of the cows, as reflected by plasma metabolites. Furthermore, protected fat with a high proportion of unsaturated FA (CaLFA) was more pronounced in increasing plasma NEFA concentrations and depressing plasma insulin concentrations than fat with a low proportion of unsaturated $\mathrm{FA}$ (PrFA).

Key words: transition cow, unsaturated fatty acid, propylene glycol

\section{INTRODUCTION}

Transition cow nutrition and management is a key factor for the health and profitability of the consequent lactation. The shift from low nutritional demands at late pregnancy to high needs at early lactation requires adaptation of the metabolic system and other physiological parameters (Bell, 1995). The DMI of cows in late pregnancy is one of the most important factors influencing the periparturient metabolic status of the cows. Drackley (1999) summarized a few studies that demonstrated a strong relationship between early postpartum DMI and the incidence of metabolic disorders.

Several nutritional strategies have been suggested to improve the adaptation of the transition cow. In a review by Grummer (1993), dietary fat was hypothesized to contribute to lower fatty acid mobilization and spare glucose by decreasing the NADPH needed for mammary fatty acid synthesis. A few reports have investigated the effects of feeding fat to dairy cows prepartum. In a study by Grum et al. (1996), a high liquid fat diet (6.5\% of diet; DM basis) that was fed from dry-off until $7 \mathrm{~d}$ before parturition decreased $\mathrm{DMI}$ and $\mathrm{NE}_{\mathrm{L}}$ intake, decreased triglyceride accumulation in the liver 
at $1 \mathrm{~d}$ postpartum, increased the NEFA concentration, and lowered the insulin concentration in plasma. In another report, lower fat supplementation to dry cows (3.64\% of diet; DM basis) did not affect peripartal DMI and $\mathrm{NE}_{\mathrm{L}}$ intake and lipid accumulation in liver tissue (Douglas et al., 2004). Douglas et al. (2004) suggested that the lower lipid accumulation in liver that was observed by Grum et al. (1996) was also associated with the decreased plasma insulin in fat-supplemented cows. In both studies, unprotected fats were used, which might have affected the digestion of other dietary components and confounded the results (Jenkins, 1993).

Dietary glucogenic precursors are also used to improve the metabolic status of the transition cow. Propylene glycol (PGLY) is a glucogenic precursor that is rapidly absorbed from the rumen for gluconeogenesis in the liver. Administration of PGLY makes a small positive contribution to energy status, and its main benefit derives from bolus administration, which increases insulin secretion (Christensen et al., 1997). In most studies, the PGLY is supplemented postcalving or at midlactation. The objectives of the present study were to examine the effects on feed intake, production, and plasma metabolites of supplying 2 ruminally inert fats containing a low or high ratio of unsaturated fatty acids (FA), or a supplement that contained $55 \%$ of dry PGLY starting at the close-up dry period.

\section{MATERIALS AND METHODS}

\section{Cows and Treatments}

A portion of the results of the current project were reported elsewhere in relation to early postpartum ovarian follicles (Moallem et al., 2007). The experimental protocol for the study was approved by the Volcani Center Animal Care Committee and was conducted at the Volcani Center experimental farm in Bet Dagan, Israel. Fifty-three multiparous Israeli Holstein cows were used in the study. The study was conducted from September to April to avoid the effects of heat stress, and during 2 consecutive winters. Cows were dried off at $217 \mathrm{~d}$ of pregnancy, housed in one group, and fed the control diet (Table 1). Twenty-eight days before expected parturition, at $249 \mathrm{~d}$ of pregnancy, the cows were group-housed in covered loose pens with adjacent outside yards. The barn was equipped with a real-time electronic individual feeding system. Each station was equipped with an individual identification system (S.A.E, Kibbutz Afikim, Israel) that allowed each cow to enter a specific station. After $7 \mathrm{~d}$ of adaptation, at $256 \mathrm{~d}$ of pregnancy, the cows were stratified into 4 treatments, with 13 to 14 cows in each treatment group. The cows were divided randomly within stratum, and strata were defined by the following parameters: previous lac-
Table 1. Ingredients and chemical composition of dry cow diets

\begin{tabular}{|c|c|c|c|c|}
\hline \multirow[b]{2}{*}{ Item } & \multicolumn{4}{|c|}{ Treatment $^{1}$} \\
\hline & Control & PGLY & PrFA & CaLFA \\
\hline & & $-\% \mathrm{o}$ & $\mathrm{M}-$ & 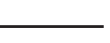 \\
\hline \multicolumn{5}{|l|}{ Ingredient } \\
\hline Corn grain, ground & 12.9 & 12.8 & 4.9 & 4.8 \\
\hline Barley grain, rolled & 6.9 & 6.5 & 5.9 & 5.8 \\
\hline Rapeseed meal & 0.4 & 0.3 & 0.3 & 0.3 \\
\hline Corn gluten meal & 1.2 & 1.1 & 1.0 & 1.0 \\
\hline Soybean meal & 1.9 & 1.8 & 1.6 & 1.6 \\
\hline Sunflower meal & 0.7 & 0.6 & 0.6 & 0.6 \\
\hline Corn gluten feed & 2.9 & 2.7 & 2.4 & 2.4 \\
\hline Cottonseed & 1.7 & 1.6 & 1.5 & 1.5 \\
\hline Wheat silage & 4.6 & 4.3 & 3.9 & 3.9 \\
\hline Corn silage & 4.5 & 4.1 & 3.8 & 3.7 \\
\hline Dried distillers grain & 1.4 & 1.3 & 1.2 & 1.2 \\
\hline Molasses & 0.8 & 0.8 & 0.7 & 0.7 \\
\hline Oat hay & 59.0 & 53.8 & 69.6 & 70.0 \\
\hline Salt & 0.5 & 0.5 & 0.4 & 0.4 \\
\hline Calcium bicarbonate & 0.2 & 0.2 & 0.2 & 0.2 \\
\hline Vitamins and minerals ${ }^{2}$ & 0.04 & 0.03 & 0.03 & 0.03 \\
\hline \multicolumn{5}{|l|}{ Supplement } \\
\hline ProGlyc 55 & & 7.2 & & \\
\hline Energy Booster 100 & & & 1.9 & \\
\hline Megalac- $\mathrm{R}$ & & & & 1.7 \\
\hline \multicolumn{5}{|l|}{ Chemical composition } \\
\hline $\mathrm{NE}_{\mathrm{L}},{ }^{3} \mathrm{Mcal} / \mathrm{kg}$ of $\mathrm{DM}$ & 1.48 & 1.57 & 1.49 & 1.49 \\
\hline $\mathrm{CP}$ & 12.0 & 12.0 & 12.0 & 12.0 \\
\hline Ether extract & 1.5 & 1.6 & 3.0 & 2.9 \\
\hline NDF & 45.0 & 42.0 & 48.0 & 49.0 \\
\hline $\mathrm{Ca}$ & 0.6 & 0.7 & 0.6 & 0.8 \\
\hline $\mathrm{P}$ & 0.3 & 0.3 & 0.3 & 0.3 \\
\hline
\end{tabular}

${ }^{1}$ Treatments: cows were fed from $256 \mathrm{~d}$ of pregnancy either a dry cow ration and postpartum fed a lactating cow diet (control); $909 \mathrm{~g} /$ d per cow of ProGlyc 55 (Kimtec, Heijningen, the Netherlands) through 21 DIM (PGLY); 230 g/d per cow of Energy Booster 100 (Milk Specialties, Dundee, IL) through 100 DIM (PrFA); or 215 g/d per cow of Megalac-R (Church and Dwight, Princeton, NJ) through 100 DIM (CaLFA).

${ }^{2}$ Contained $20,000,000 \mathrm{IU} / \mathrm{kg}$ of vitamin A, 2,000,000 IU/kg of vitamin D, 15,000 IU/kg of vitamin E, $6,000 \mathrm{mg} / \mathrm{kg}$ of $\mathrm{Mn}, 6,000 \mathrm{mg} / \mathrm{kg}$ of $\mathrm{Zn}, 2,000 \mathrm{mg} / \mathrm{kg}$ of Fe, $1,500 \mathrm{mg} / \mathrm{kg}$ of Cu, $120 \mathrm{mg} / \mathrm{kg}$ of I, $50 \mathrm{mg} /$ $\mathrm{kg}$ of Se, and $20 \mathrm{mg} / \mathrm{kg}$ of Co.

${ }^{3}$ Calculated using NRC (2001) recommendations.

tation milk and fat production, parity, BW, and BCS. The following treatments commenced at $256 \mathrm{~d}$ of pregnancy: 1) cows in the control group were fed a dry cow diet and postpartum were fed a lactating cow diet according to NRC (2001) recommendations; 2) cows in the PGLY group were fed prepartum a dry cow diet and postpartum fed a lactating cow diet supplemented with $909 \mathrm{~g} / \mathrm{d}$ per cow of glucogenic additive containing 55\% dry PGLY (ProGlyc 55, Kimtec, Heijningen, the Netherlands), equal to $500 \mathrm{~g} / \mathrm{d}$ of pure PGLY, through 21 DIM; 3 ) cows in the prilled fatty acid (PrFA) group were fed a dry cow diet supplemented with $230 \mathrm{~g} / \mathrm{d}$ per cow of PrFA (Energy Booster 100, Milk Specialties, Dundee, IL) and postpartum fed a lactating cow diet supplemented with 230 g/d per cow PrFA through 100 DIM; and 4) cows in the calcium soaps of long-chain fatty 
Table 2. Basal lactating cow diet ingredients and chemical composition

\begin{tabular}{lc}
\hline Item & Amount, \% of DM \\
\hline Ingredient & \\
Corn grain, ground & 15.5 \\
Barley grain, rolled & 18.7 \\
Rapeseed meal & 1.0 \\
Corn gluten meal & 3.2 \\
Soybean meal & 5.2 \\
Sunflower meal & 1.8 \\
Corn gluten feed & 7.7 \\
Cottonseed & 4.7 \\
Wheat silage & 12.5 \\
Corn silage & 12.0 \\
Dried distillers grain & 3.9 \\
Molasses & 0.6 \\
Vetch hay & 2.2 \\
Oats hay & 8.9 \\
Soybean oil & 0.1 \\
Salt & 1.4 \\
Calcium bicarbonate & 0.5 \\
Vitamins and minerals ${ }^{1}$ & 0.1 \\
Chemical composition & \\
NE ${ }^{2}{ }^{2}$ Mcal/kg & 1.725 \\
CP & 17.0 \\
RUP & 6.0 \\
ADF & 19.4 \\
NDF & \\
NDF, ${ }^{3}$ forage & 31.7 \\
Ether extract & 18.7 \\
Ca & 3.55 \\
P & 0.9 \\
\hline
\end{tabular}

${ }^{1}$ Contained 20,000,000 IU of vitamin $\mathrm{A} / \mathrm{kg}, 2,000,000 \mathrm{IU}$ of vitamin $\mathrm{D} / \mathrm{kg}, 15,000 \mathrm{IU} / \mathrm{kg}$ of vitamin E, $6,000 \mathrm{mg} / \mathrm{kg}$ of $\mathrm{Mn}, 6,000 \mathrm{mg} / \mathrm{kg}$ of $\mathrm{Zn}, 2,000 \mathrm{mg} / \mathrm{kg}$ of $\mathrm{Fe}, 1,500 \mathrm{mg} / \mathrm{kg}$ of $\mathrm{Cu}, 120 \mathrm{mg} / \mathrm{kg}$ of I, $50 \mathrm{mg} / \mathrm{kg}$ of Se, and $20 \mathrm{mg} / \mathrm{kg}$ of Co.

${ }^{2}$ Calculated using NRC (2001) recommendations.

${ }^{3} \mathrm{NDF}$ from forage and nonforage sources.

${ }^{4} \mathrm{NDF}$ from forage sources.

acids (CaLFA) group were fed a dry cow diet supplemented with $215 \mathrm{~g} / \mathrm{d}$ per cow of CaLFA (Megalac-R, Church \& Dwight, Princeton, NJ) and postpartum fed a lactating diet supplemented with $215 \mathrm{~g} / \mathrm{d}$ per cow of CaLFA through 100 DIM. The composition and content of lactating cow diets are presented in Table 2. The content of the ProGlyc 55 supplement was $4 \%$ CP, $1.5 \%$ ether extract, $55 \% 1.2$ propandiol, $32 \%$ carbohydrates, 95\% OM, 2.6\% Ca, and 0.4\% P (DM basis). The FA profile of Energy Booster 100 was $28.2 \%$ palmitic acid (16:0), $51.2 \%$ stearic acid (18:0), 8.4\% oleic acid (18:1), $1.5 \%$ linoleic acid (18:2), $0.1 \%$ linolenic acid (18:3), and $10.6 \%$ other FA (measured as a percentage of total FA). The FA profile of Megalac-R was $17.4 \%$ palmitic acid (16:0), $2.1 \%$ stearic acid (18:0), 33.6\% oleic acid (18:1), $30.5 \%$ linoleic acid (18:2), $2.4 \%$ linolenic acid (18:3), and $14 \%$ other FA. The diets were formulated to be isoeneregetic, except for PGLY, which was higher by 0.78 $\mathrm{Mcal} / \mathrm{d}$ per cow. The energy contents of all supplements used in this study were calculated according to the man- ufacturer's specifications, which were 2.5, 6.0, and 6.6 Mcal of $\mathrm{NE}_{\mathrm{L}} / \mathrm{kg}$ of DM for ProGlyc 55, Energy Booster 100 , and Megalac-R, respectively.

Daily individual intake was recorded. The cows were fed once a day at $1100 \mathrm{~h}$ at $107 \%$ of expected intake, which was adjusted according to the previous day's intake. The fat supplements were individually handmixed into the upper third of the TMR at feeding. The PGLY supplement was hand-mixed with the TMR and offered to each cow $5 \mathrm{~h}$ after the regular feeding (1600 h) to extend insulin release and its action beyond the normal feeding-associated insulin release period.

During the dry period, the cows were weighed weekly, and after calving, cows were weighed automatically 3 times daily after each milking with a walking electronic scale. Body condition score ( 1 to 5 scale) was determined weekly by a technician from $249 \mathrm{~d}$ of pregnancy until the end of the study.

The cows were milked 3 times daily and milk production was recorded electronically. Milk solids content was determined from 3 consecutive milkings every 2 wk until 100 DIM. Milk fat, protein, and lactose were determined by mean infrared analysis (standard IDF $141 \mathrm{C}, 2000)$ at the Israeli Cattle Breeders Association (Caesarea, Israel).

Blood samples were collected from the jugular vein into vacuum tubes (Becton Dickinson Systems, Cowley, UK) 3 times a week (on Sunday, Tuesday, and Thursday) from $249 \mathrm{~d}$ of pregnancy until 70 DIM. Additional blood samples for glucose analysis were collected into tubes containing lithium chloride and L-iodoacetate (BD Vacutainer, Belliver Industrial Estate, Plymouth, UK) until 30 DIM. The blood samples were collected after the morning milking at $0800 \mathrm{~h}(3 \mathrm{~h}$ before the daily feeding), and plasma was separated immediately from blood samples and stored at $-18^{\circ} \mathrm{C}$ until analysis.

\section{Chemical Analysis}

Total mixed rations were sampled weekly and DM, $\mathrm{CP}, \mathrm{NDF}, \mathrm{ADF}, \mathrm{Ca}$, and $\mathrm{P}$ were determined. Feed samples were dried at $65^{\circ} \mathrm{C}$ for $24 \mathrm{~h}$ and then ground to pass through a 1.0-mm screen (Retsch S-M-100; Retsch $\mathrm{GmbH}$, Haan, Germany). The ground samples were dried at $100^{\circ} \mathrm{C}$ for $24 \mathrm{~h}$ and analyzed for $\mathrm{N}$ (AOAC, 1990; method 984.13), Ca (AOAC, 1990; method 935.13), and $\mathrm{P}$ (AOAC, 1990; method 964.06); NDF and ADF content were determined with Ankom equipment (Ankom Technology, Fairport, NY; NDF with $\alpha$-amylase and sodium sulfite). Net energy for lactation values for feedstuffs that were used in the formulated diets were calculated with the NRC values (NRC, 2001) except for the added supplements. Plasma glucose was determined by a glucose reagent kit (Glucose UV $10 \times 50 \mathrm{~mL}$, Raichem, San 
Diego, CA). Plasma BHBA was determined by a kit (Ranbut D-3-hydroxybutyrate, Randox, Crumlin, UK). Plasma NEFA was determined by a kit (Wako NEFA C test kit, Wako Chemicals GmbH, Neuss, Germany). Plasma insulin was determined by RIA (Diagnostic Products, Los Angeles, CA). The intra- and interassay coefficients of variation for the insulin assay were 7.2 and $5.1 \%$, respectively.

\section{Statistical Analysis}

Continuous variables (intake, milk production, and plasma metabolites) were analyzed as repeated measurements using PROC MIXED of SAS (version 8.1, SAS Institute, 2000). The interactions of treatment $x$ parity, treatment $\times$ DIM, parity $\times$ DIM, and treatment $\times$ parity $\times$ DIM were tested for each dependent variable. No treatment $\times$ parity, parity $\times$ DIM, and treatment $\times$ parity $\times$ DIM interactions were significant and were therefore excluded from the model.

The model used was

$$
\begin{gathered}
\mathrm{Y}_{\mathrm{ijklm}}=\mu+\mathrm{T}_{\mathrm{i}}+\mathrm{L}_{\mathrm{j}}+\mathrm{C}(\mathrm{T} \times \mathrm{L})_{\mathrm{ijk}}+\mathrm{DIM}_{\mathrm{ijkl}}+\mathrm{DIM}_{\mathrm{ijkl}} \\
\times \mathrm{DIM}_{\mathrm{ijkl}}+\mathrm{DIM}_{\mathrm{ijkl}} \times \mathrm{DIM}_{\mathrm{ijkl}} \times \mathrm{DIM}_{\mathrm{ijkl}}+E_{\mathrm{ijklm}}
\end{gathered}
$$

where $\mu$ is the overall mean; $T_{i}$ is the treatment effect (where $\mathrm{i}$ is 1 to 4 ); $\mathrm{L}_{\mathrm{j}}$ is parity (where $\mathrm{j}$ is 2 or $>2$; $\mathrm{C}(\mathrm{T}$ $\times L)_{i j k}$ is cow ${ }_{k}$ nested in treatment ${ }_{\mathrm{i}}$ and cow nested in parity $_{\mathrm{j}}$; DIM $\mathrm{Dijkl}_{\mathrm{ijl}}$ is DIM as a continuous variable; and $E_{\mathrm{ijklm}}$ is the random residual. Least squares means and adjusted SEM are presented in the tables; $P<0.05$ was accepted as significant unless otherwise stated.

\section{RESULTS}

The duration of gestation was significantly longer in the PGLY group $(281 \pm 1.4 \mathrm{~d})$ than in all other groups $(277 \pm 1.3,277 \pm 0.9$, and $276 \pm 1.0 \mathrm{~d}$ for the control, PrFA, and CaLFA groups, respectively; $P<0.04$ ). No twin births occurred in the control and PGLY groups, whereas one twin birth occurred in the PrFA group and one in the CaLFA group. No significant differences among groups were observed in calf (male and female) BW at calving, and the average calf BW were $40.0 \pm$ $1.6,40.9 \pm 1.7,41.7 \pm 1.1$, and $40.0 \pm 1.2 \mathrm{~kg}$ for the control, PGLY, PrFA, and CaLFA groups, respectively.

\section{DMI and Milk Production}

Prepartum DMI results are presented in Table 3 and in Figure 1. Feeding both fat supplements prepartum decreased the intake, and the daily average DMI in the PrFA and CaLFA groups were decreased by 6.7 and $15.7 \%$, respectively, as compared with the control group
$(P<0.01)$. No treatment $\times$ DIM effect was observed for prepartum intake. The daily average $\mathrm{NE}_{\mathrm{L}}$ intake prepartum was higher in the control and PGLY groups than in the PrFA and CaLFA groups. Daily average $\mathrm{DMI}$ and $\mathrm{NE}_{\mathrm{L}}$ intakes prepartum in the PrFA group were higher than in the CaLFA group $(P<0.006)$. The daily average DMI from calving until 100 DIM in the PGLY group was similar to that in the PrFA group and was higher than those in the control and CaLFA groups (Table 3 and Figure 2; $P<0.05$ ). The treatment $\times$ DIM effect through 100 DIM was significant $(P<0.0001)$. Analysis of the DMI for 50 DIM showed higher intakes in all groups compared with that in the CaLFA group $(P<0.03)$. The daily average $\mathrm{NE}_{\mathrm{L}}$ intake postpartum in the PrFA group was $3.1 \%$ higher than that in the CaLFA group $(P<0.03)$.

As can be seen in Table 3, cows in both fat-supplemented groups (PrFA and CaLFA) produced $4.5 \%$ more milk than did cows in the control and PGLY groups ( $P$ $<0.02$ ), whereas no differences were observed between the control and PGLY groups. No differences in fat percentage or yield were observed among groups. The protein percentage in the PrFA and CaLFA groups was lower than that in the control group $(P<0.05)$, with no differences in protein yield among groups. No differences were observed among groups in FCM 3.5\% yields. Efficiency calculations are presented in Table 3 . The gross efficiency of FCM (3.5\%) from DM was higher in the CaLFA group than in the control and PGLY groups $(P<0.02)$, whereas the efficiencies of FCM $(3.5 \%)$ and total energy produced in milk from $\mathrm{NE}_{\mathrm{L}}$ intake were not different among groups.

\section{BW, BCS, and Plasma Metabolites}

The peripartum changes in BCS over time are presented in Figure 3. No differences were observed in BW (data not shown) and BCS prepartum among groups, and an average increase of $25 \mathrm{~kg}$ of BW and 0.25 units of BCS were observed from $28 \mathrm{~d}$ prepartum to parturition. No differences in BW changes postpartum among groups were observed. The average BCS at calving were $3.17,3.22,3.31$, and 3.40 (pooled SEM $=0.027$ ) for the control, PGLY, PrFA, and CaLFA groups, respectively. Cows in the PrFA and CaLFA groups lost more units of BCS than did those in other groups $(P<0.01)$, and at 100 DIM the average BCS in the control (2.62 \pm 0.07$)$ and PGLY $(2.61 \pm 0.08)$ groups were higher than those in the PrFA $(2.35 \pm 0.06)$ and CaLFA $(2.34 \pm 0.06)$ groups (pooled SEM $=0.07 ; P<0.006$ ).

Mean plasma concentrations of glucose, NEFA, BHBA, and insulin from $14 \mathrm{~d}$ prepartum until $17 \mathrm{~d}$ postpartum are presented in Table 4 and Figure 4. Prepartum and postpartum plasma glucose concentrations 
Table 3. Least squares means of $\mathrm{DMI}$ and $\mathrm{NE}_{\mathrm{L}}$ intake pre- and postpartum, and production and efficiencies until 100 DIM

\begin{tabular}{|c|c|c|c|c|c|}
\hline \multirow[b]{2}{*}{ Item } & \multicolumn{4}{|c|}{ Treatment $^{1}$} & \multirow[b]{2}{*}{ SEM } \\
\hline & Control & PGLY & PrFA & CaLFA & \\
\hline Cows, $\mathrm{n}$ & 14 & 13 & 14 & 14 & \\
\hline $\begin{array}{l}\text { DMI, kg/d } \\
\text { Prepartum } \\
\text { Postpartum }\end{array}$ & $\begin{array}{l}12.1^{\mathrm{a}} \\
24.3^{\mathrm{b}}\end{array}$ & $\begin{array}{l}11.5^{\mathrm{ab}} \\
25.0^{\mathrm{a}}\end{array}$ & $\begin{array}{l}11.4^{\mathrm{b}} \\
25.1^{\mathrm{a}}\end{array}$ & $\begin{array}{l}10.5^{\mathrm{c}} \\
24.3^{\mathrm{b}}\end{array}$ & $\begin{array}{l}0.2 \\
0.2\end{array}$ \\
\hline $\begin{array}{l}\mathrm{NE}_{\mathrm{L}} \text { intake, Mcal/d } \\
\text { Prepartum } \\
\text { Postpartum }\end{array}$ & $\begin{array}{l}17.9^{\mathrm{a}} \\
42.3^{\mathrm{c}}\end{array}$ & $\begin{array}{l}18.1^{\mathrm{a}} \\
43.5^{\mathrm{ab}}\end{array}$ & $\begin{array}{l}17.0^{\mathrm{b}} \\
44.4^{\mathrm{a}}\end{array}$ & $\begin{array}{l}15.7^{\mathrm{c}} \\
43.1^{\mathrm{bc}}\end{array}$ & $\begin{array}{l}0.3 \\
0.4\end{array}$ \\
\hline $\begin{array}{l}\text { DMI, \% of BW } \\
\text { Prepartum } \\
\text { Postpartum }\end{array}$ & $\begin{array}{l}1.92^{\mathrm{a}} \\
4.13^{\mathrm{bc}}\end{array}$ & $\begin{array}{l}1.76^{\mathrm{b}} \\
4.24^{\mathrm{a}}\end{array}$ & $\begin{array}{l}1.76^{\mathrm{b}} \\
4.21^{\mathrm{ab}}\end{array}$ & $\begin{array}{l}1.55^{\mathrm{c}} \\
4.10^{\mathrm{c}}\end{array}$ & $\begin{array}{l}0.03 \\
0.03\end{array}$ \\
\hline $\begin{array}{l}\text { Milk, kg/d } \\
\text { Milk fat } \\
\% \\
\text { kg/d }\end{array}$ & $\begin{array}{c}42.3^{\mathrm{b}} \\
\\
3.70 \\
1.61\end{array}$ & $\begin{array}{l}42.7^{\mathrm{b}} \\
\\
3.65 \\
1.56\end{array}$ & $\begin{array}{l}44.4^{\mathrm{a}} \\
3.52 \\
1.56\end{array}$ & $\begin{array}{r}44.3^{\mathrm{a}} \\
\\
3.65 \\
1.61\end{array}$ & $\begin{array}{l}0.5 \\
0.08 \\
0.04\end{array}$ \\
\hline $\begin{array}{l}\text { Milk protein } \\
\% \\
\mathrm{~kg} / \mathrm{d}\end{array}$ & $\begin{array}{l}3.09^{\mathrm{a}} \\
1.33\end{array}$ & $\begin{array}{l}3.07^{\mathrm{ab}} \\
1.31\end{array}$ & $\begin{array}{l}2.94^{\mathrm{bc}} \\
1.33\end{array}$ & $\begin{array}{l}2.91^{\mathrm{c}} \\
1.29\end{array}$ & $\begin{array}{l}0.04 \\
0.03\end{array}$ \\
\hline 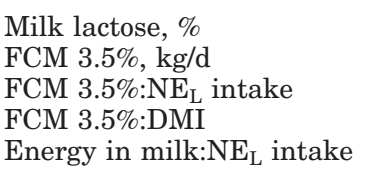 & $\begin{array}{l}5.10^{\mathrm{a}} \\
42.9 \\
1.02 \\
1.77^{\mathrm{b}} \\
0.71\end{array}$ & $\begin{array}{l}5.06^{\mathrm{ab}} \\
43.6 \\
1.02 \\
1.77^{\mathrm{b}} \\
0.70\end{array}$ & $\begin{array}{l}5.03^{\mathrm{ab}} \\
43.7 \\
1.04 \\
1.83^{\mathrm{ab}} \\
0.71\end{array}$ & $\begin{array}{l}4.97^{\mathrm{b}} \\
44.4 \\
1.06 \\
1.88^{\mathrm{a}} \\
0.72\end{array}$ & $\begin{array}{l}0.04 \\
0.6 \\
0.01 \\
0.02 \\
0.01\end{array}$ \\
\hline
\end{tabular}

${ }^{\mathrm{a}-\mathrm{c}}$ Means within a row with different subscripts differ $(P<0.05)$.

${ }^{1}$ Treatments: cows were fed from $256 \mathrm{~d}$ of pregnancy either a dry cow ration and postpartum fed a lactating cow diet; 500 g/d per cow of dry propylene glycol (ProGlyc 55, Kimtec, Heijningen, the Netherlands) through 21 DIM (PGLY); 230 g/d per cow of Energy Booster 100 (Milk Specialties, Dundee, IL) through 100 DIM (PrFA); or 215 g/d per cow of Megalac-R (Church \& Dwight, Princeton, NJ) through 100 DIM (CaLFA).

were higher in the PGLY group than in the PrFA and CaLFA groups, with no differences among all other groups. In all groups, the typical increase in plasma

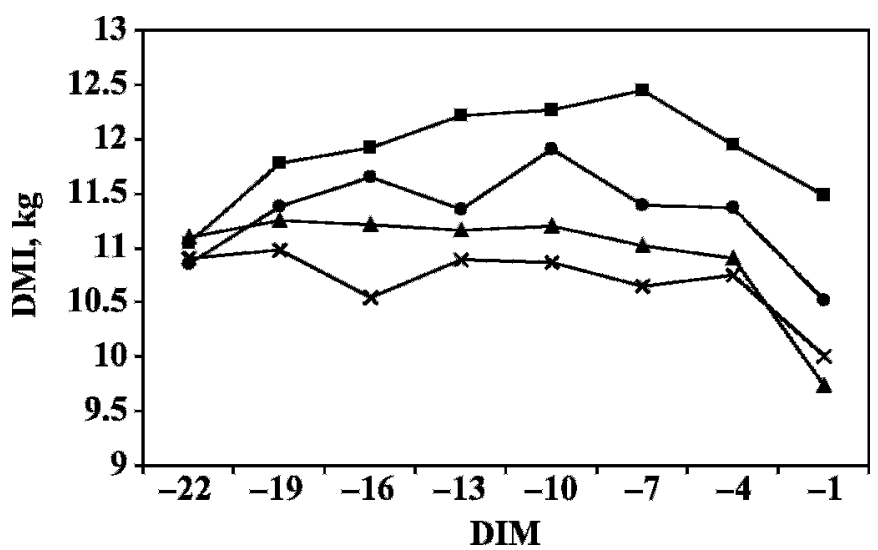

Figure 1. Least squares means of prepartum DMI in cows fed from $256 \mathrm{~d}$ of pregnancy either a control diet (ם), a diet supplemented with $500 \mathrm{~g} / \mathrm{d}$ per cow of dry propylene glycol (ProGlyc 55, Kimtec, Heijningen, the Netherlands; - ) until 21 DIM, a diet supplemented with $230 \mathrm{~g} / \mathrm{d}$ per cow of prilled fat (Energy Booster 100; $\boldsymbol{\Lambda}$ ) until 100 DIM, or a diet supplemented with $215 \mathrm{~g} / \mathrm{d}$ per cow of calcium soaps of fatty acids (Megalac-R; $\times$ ) until 100 DIM. Pooled SEM values were $0.22 \mathrm{~kg} / \mathrm{d}$.
NEFA concentrations was demonstrated; however, in both fat-supplemented groups, the increase commenced at approximately $10 \mathrm{~d}$ before calving compared with

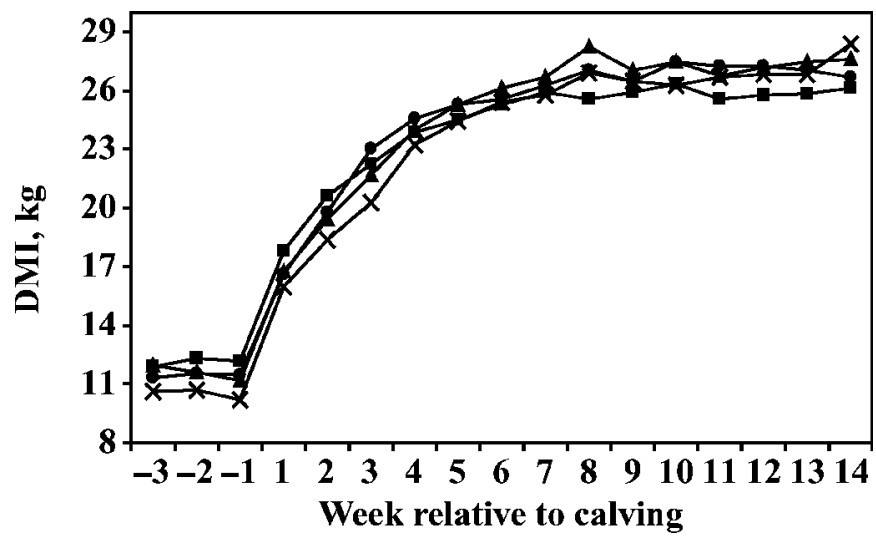

Figure 2. Least squares means of peripartum DMI in cows fed from $256 \mathrm{~d}$ of pregnancy either a control diet ( $\mathbf{\square})$, a diet supplemented with $500 \mathrm{~g} / \mathrm{d}$ per cow of dry propylene glycol (ProGlyc 55, Kimtec, Heijningen, the Netherlands; 0 ) until 21 DIM, a diet supplemented with $230 \mathrm{~g} / \mathrm{d}$ per cow of prilled fat (Energy Booster 100; $\boldsymbol{\Delta}$ ) until 100 DIM, or a diet supplemented with $215 \mathrm{~g} / \mathrm{d}$ per cow of calcium soaps of fatty acids (Megalac-R; $\times$ ) until 100 DIM. Pooled SEM values were 0.22 and $0.23 \mathrm{~kg} / \mathrm{d}$ for prepartum and postpartum data, respectively. 


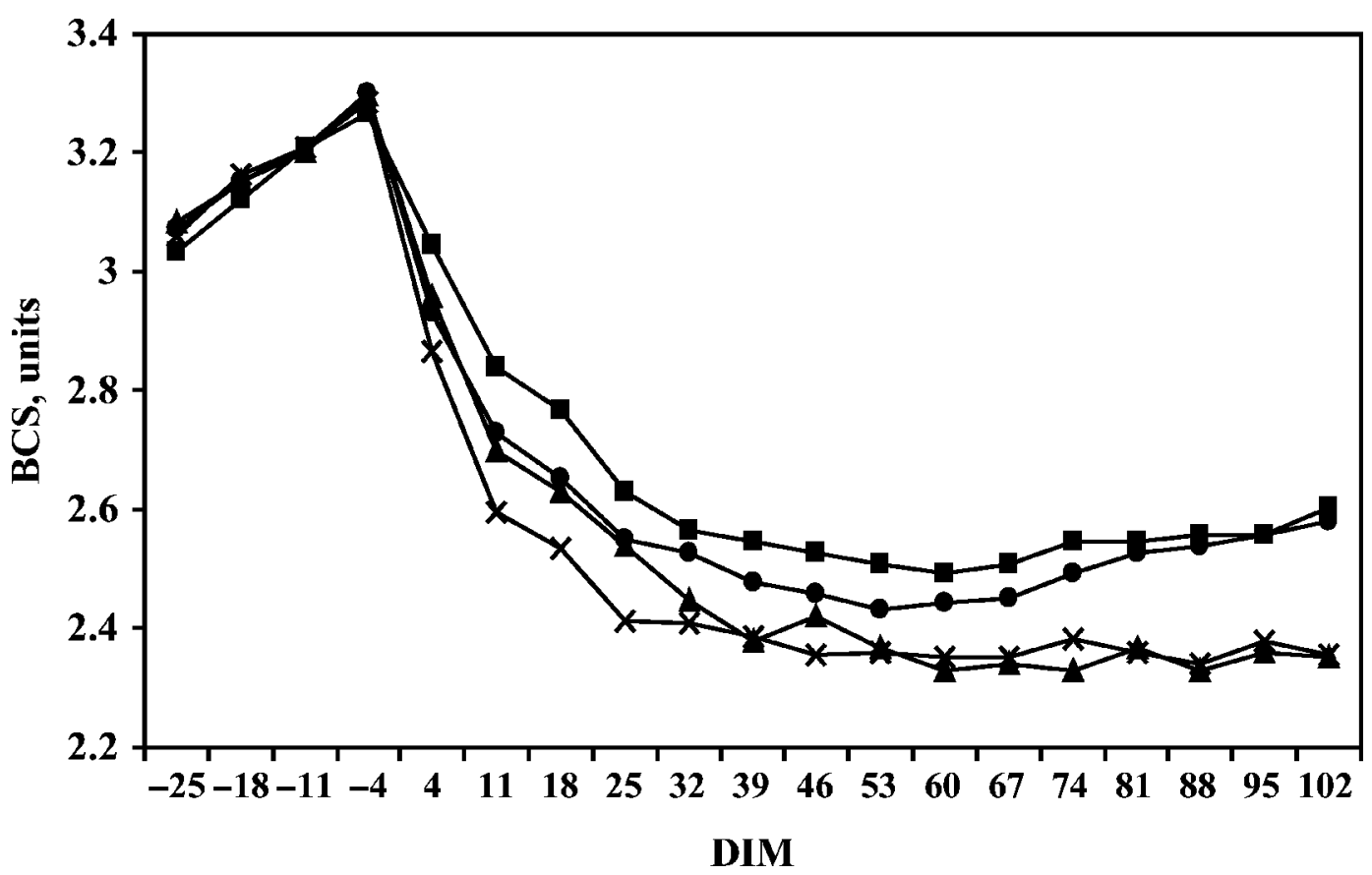

Figure 3. Least squares means of BCS in cows fed from $256 \mathrm{~d}$ of pregnancy either a control diet ( $\mathbf{\square})$, a diet supplemented with 500 g/d per cow of dry propylene glycol (ProGlyc 55, Kimtec, Heijningen, the Netherlands; ๑) until 21 DIM, a diet supplemented with 230 g/d per cow of prilled fat (Energy Booster 100; $\mathbf{\Delta}$ ) until 100 DIM, or a diet supplemented with $215 \mathrm{~g} / \mathrm{d}$ per cow of calcium soaps of fatty acids (Megalac-R; $\times$ ) until 100 DIM.

the control and PGLY groups, in which the increase started by $4 \mathrm{~d}$ before calving. Prepartum plasma NEFA concentrations were higher in the PrFA and CaLFA

Table 4. Least squares means of plasma metabolites and insulin concentrations pre- and postpartum

\begin{tabular}{lccccc}
\hline & \multicolumn{5}{c}{ Treatment $^{1}$} \\
\cline { 2 - 4 } Item & Control & PGLY & PrFA & CaLFA & SEM \\
\hline Cows, n & 14 & 13 & 14 & 14 & \\
Glucose, mg/dL & & & & & \\
$\quad$ Prepartum & $67.5^{\mathrm{ab}}$ & $68.6^{\mathrm{a}}$ & $65.4^{\mathrm{b}}$ & $66.1^{\mathrm{b}}$ & 0.9 \\
Postpartum & $61.3^{\mathrm{ab}}$ & $63.6^{\mathrm{a}}$ & $59.7^{\mathrm{b}}$ & $59.7^{\mathrm{b}}$ & 1.1 \\
NEFA, $\mu \mathrm{Eq} / \mathrm{L}$ & & & & & \\
Prepartum & $232.4^{\mathrm{c}}$ & $233.3^{\mathrm{c}}$ & $333.2^{\mathrm{b}}$ & $395.4^{\mathrm{a}}$ & 26.2 \\
Postpartum & $470.3^{\mathrm{c}}$ & $489.8^{\mathrm{bc}}$ & $588.1^{\mathrm{bc}}$ & $600.4^{\mathrm{ab}}$ & 46.0 \\
BHBA, mg/dL & & & & & \\
Prepartum & $3.1^{\mathrm{b}}$ & $3.1^{\mathrm{b}}$ & $4.0^{\mathrm{a}}$ & $4.3^{\mathrm{a}}$ & 0.3 \\
Postpartum & $4.5^{\mathrm{b}}$ & $4.4^{\mathrm{b}}$ & $6.3^{\mathrm{a}}$ & $7.2^{\mathrm{a}}$ & 0.4 \\
Insulin, pg/mL & $395.8^{\mathrm{a}}$ & $336.1^{\mathrm{b}}$ & $239.1^{\mathrm{c}}$ & $187.8^{\mathrm{d}}$ & 20.4 \\
Postpartum & $273.2^{\mathrm{a}}$ & $273.4^{\mathrm{a}}$ & $148.8^{\mathrm{b}}$ & $127.4^{\mathrm{b}}$ & 23.2 \\
\hline
\end{tabular}

${ }^{\mathrm{a}-\mathrm{d}}$ Means within a row with different subscripts differ $(P<0.05)$.

${ }^{1}$ Treatments: cows were fed from $256 \mathrm{~d}$ of pregnancy either a dry cow ration and postpartum fed a lactating cow diet (control); $500 \mathrm{~g} /$ d per cow of dry propylene glycol (ProGlyc 55, Kimtec, Heijningen, the Netherlands) through 21 DIM (PGLY); $230 \mathrm{~g} / \mathrm{d}$ per cow of Energy Booster 100 (Milk Specialties, Dundee, IL) through 100 DIM (PrFA); or $215 \mathrm{~g} / \mathrm{d}$ per cow of Megalac-R (Church \& Dwight, Princeton, NJ) through 100 DIM (CaLFA). groups than in the control and PGLY groups. In addition, prepartum plasma NEFA concentrations in the CaLFA group were higher than in the PrFA group $(P$ $<0.05$ ). Prepartum and postpartum BHBA concentrations were similar between the control and PGLY groups and were lower than those in both fat-supplemented groups $(P<0.007)$. The average plasma BHBA concentrations postpartum were $60 \%$ higher in the CaLFA group than in the control group $(P<0.0001)$.

In all groups, we observed a gradual decrease in plasma insulin concentrations from an average of 400 $\mathrm{pg} / \mathrm{mL}$ at $2 \mathrm{wk}$ before calving to an average of $200 \mathrm{pg} / \mathrm{mL}$ at calving (Table 4 and Figure 4 ). Insulin concentrations were higher in the control group than in both fat-supplemented groups prepartum and postpartum $(P<0.001)$. The average plasma insulin concentrations in the control and PGLY groups were 2.1-fold higher than that in the CaLFA group. The incidence of postpartum clinical events was summarized, and no significant differences in occurrence of clinical disorders were observed among groups (Table 5).

\section{DISCUSSION}

Feeding fat supplements differing in FA profiles from $3 \mathrm{wk}$ before expected parturition to 100 DIM decreased the prepartum feed intake and increased prepartum 

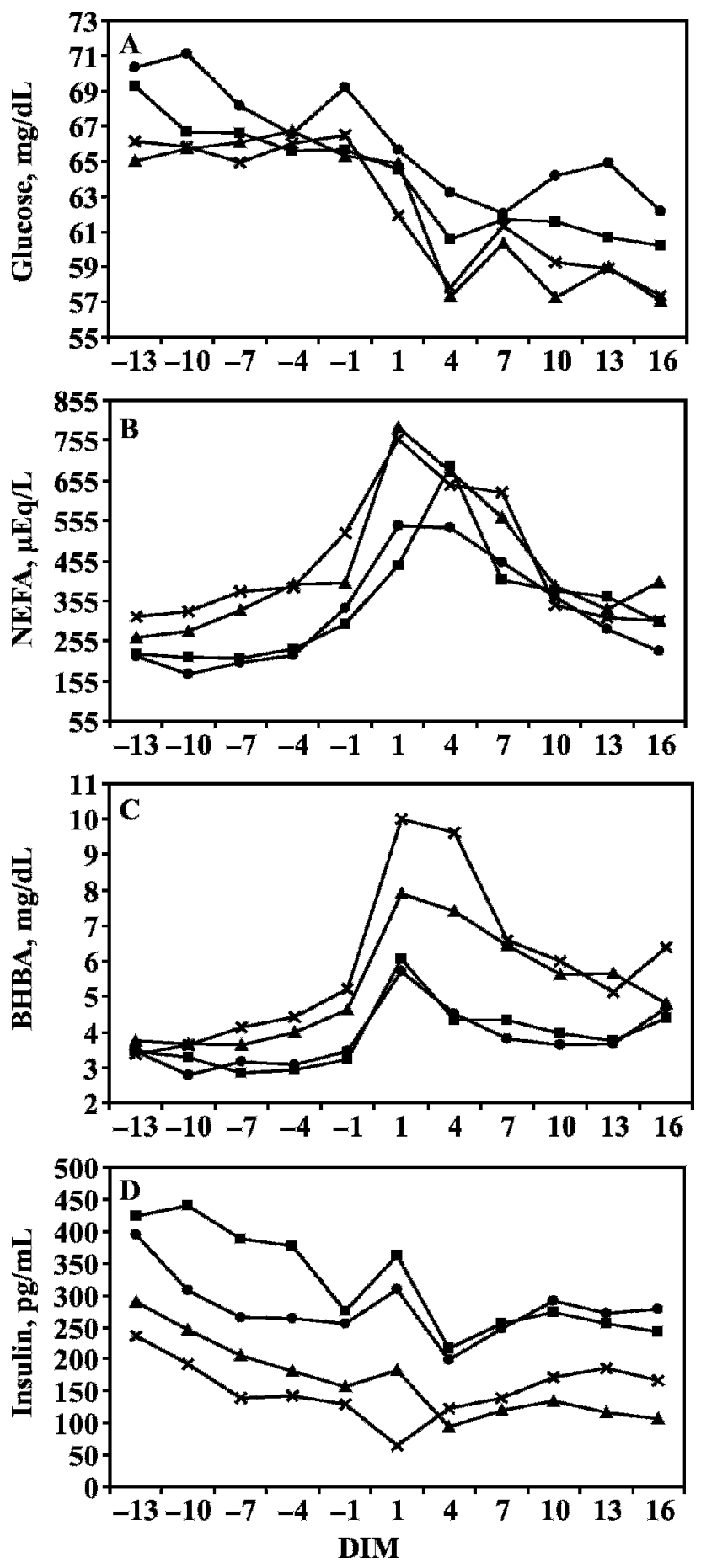

Figure 4. Least squares means of plasma concentrations of glucose (A), NEFA (B), BHBA (C), and insulin (D) in cows fed from 256 of pregnancy either a control diet (ם), a diet supplemented with 500 g/d per cow of dry propylene glycol (ProGlyc 55, Kimtec, Heijningen, the Netherlands; ) until 21 DIM, a diet supplemented with 230 g/ d per cow of prilled fat (Energy Booster 100; $\Delta$ ) until 100 DIM, a diet supplemented with $215 \mathrm{~g} / \mathrm{d}$ per cow of calcium soaps of fatty acids (Megalac-R; $\times$ ) until 100 DIM. Prepartum pooled SEM values were $0.9,26.2,0.3$ and 20.4 for glucose, NEFA, BHBA and insulin, respectively. Postpartum pooled SEM values were 1.1, 46.0, 0.4, and 23.2 for glucose, NEFA, BHBA, and insulin, respectively.
Table 5. Health problems diagnosed until $3 \mathrm{wk}$ postpartum

\begin{tabular}{lcccc}
\hline & \multicolumn{4}{c}{ Treatment $^{1}$} \\
\cline { 2 - 5 } Item & Control & PGLY & PrFA & CaLFA \\
\hline Cows, n & 14 & 13 & 13 & 14 \\
Twin births, n & 0 & 0 & 1 & 1 \\
Retained placenta, n & 0 & 1 & 2 & 1 \\
Endometritis, n & 1 & 4 & 4 & 4 \\
Ketosis, n & 0 & 1 & 1 & 1 \\
Mastitis, n & 1 & 2 & 0 & 0 \\
Milk fever, n & 0 & 0 & 0 & 0 \\
\hline
\end{tabular}

${ }^{1}$ Treatments: cows were fed from $256 \mathrm{~d}$ of pregnancy either a dry cow ration and postpartum fed a lactating cow diet (control); 500 g/d per cow of dry propylene glycol (ProGlyc 55, Kimtec, Heijningen, the Netherlands) through 21 DIM (PGLY); $230 \mathrm{~g} / \mathrm{d}$ per cow of Energy Booster 100 (Milk Specialties, Dundee, IL) through 100 DIM (PrFA); or $215 \mathrm{~g} / \mathrm{d}$ per cow of Megalac-R (Church \& Dwight, Princeton, NJ) through 100 DIM (CaLFA).

NEFA and peripartum BHBA concentrations in plasma. In addition, both fat supplements decreased peripartum plasma insulin concentrations as compared with concentrations of the control and PGLY groups. Differences were observed between the PrFA and CaLFA groups; peripartum $\mathrm{DMI}$ and $\mathrm{NE}_{\mathrm{L}}$ intake by cows fed PrFA were higher than those in cows fed CaLFA. In addition, prepartum plasma concentrations of NEFA were lower and concentrations of insulin were higher in the PrFA group than in the CaLFA group.

\section{DMI}

In the current study, a dramatic decrease occurred in DMI as calving approached in all groups during the last week of pregnancy (an average decrease of 2 to $3 \%$ from 14 to $7 \mathrm{~d}$ prepartum, and by $14 \%$ from 7 to 1 d prepartum), with no treatment $\times$ time effect. These findings are in contrast to other reports, in which a gradual decrease of more than $30 \%$ was observed in DMI during the last $21 \mathrm{~d}$ prepartum (Hayirli et al., 2002; Douglas et al., 2004, 2006). However, the results from the current study confirm a report by Grum et al. (1996), in which a decrease in DMI of less than $10 \%$ during late pregnancy was observed. Coppock et al. (1972) fed 4 diets that differed in forage:concentrate ratio (from 75:25 to 30:70, respectively) and found a significant decrease in DMI as calving approached for all groups except for the group that was fed $75 \%$ forage in the diet. In another report, a higher content of concentrate in the dry cow diet increased the DMI prepartum, but the advantage of the high concentrate content was diminished as calving approached, and a severe decrease in DMI was observed during the final week before parturition (Kunz et al., 1985). In the study by Grum et al. (1996), the NDF content of the dry cow diets was extremely high (approximately $60 \%$ of DM); 
however, in the current study the NDF content was 44 to $49 \%$, which was very similar to the reports of Douglas et al. $(2004,2006)$. The forage source, rather than the absolute forage content of the diets, and the relatively high proportion of oat hay and low proportion of silages included in the diets in both studies seems to have been the reason for the lower rate of DMI decline that was observed in the current study and in that of Grum et al. (1996) as compared with other reports, in which the diets included a high proportion of concentrates or silages (Grummer, 1995; Douglas et al., 2004, 2006). These differences in diet characteristics might also explain the differences in DMI as a percentage of BW, which ranged in the current study between 1.55 to $1.92 \%$ and were much lower than the $2.2 \%$ reported by Douglas et al. (2006).

Lower feed intake was observed in the CaLFA group than in the PrFA group prepartum and postpartum. For postpartum intake until 100 DIM, there was a significant treatment $\times$ DIM interaction, which showed increased intake in the PrFA group after peak lactation as compared with the CaLFA group. These data are consistent with other studies demonstrating a decrease in intake with increased content of unsaturated FA (Drackley et al., 1992; Bremmer et al., 1998; Harvatine and Allen, 2005). Drackley et al. (1992) suggested that the unsaturated long-chain FA that reach the intestine affect the gastrointestinal motility and consequently decrease the DMI. An inhibitory effect of intestinal infusion of unsaturated long-chain FA on forestomach motility also was found in sheep (Nicholson and Omer, 1983). In a recent study reported by Relling and Reynolds (2007), higher concentrations in plasma of glucagon-like peptide 1 amide (GLP-1), and cholecystokinin8 were demonstrated in cows fed monounsaturated FA or polyunsaturated FA as compared with cows fed saturated FA. Both glucagon-like peptide 1 amide and cholecystokinin- 8 are gut peptides that have been postulated as feed intake mediators in dairy cows (Choi and Palmquist, 1996; Benson and Reynolds, 2001). In the current study, rumen-inert fats were used, and it is plausible to assume that higher amounts of unsaturated longchain FA reached the intestine, which led to lower intake.

Douglas et al. (2006) and Agenäs et al. (2003) reported improved postpartum consumption for cows that were feed restricted prepartum. However, in our study, data across treatments indicated a positive correlation between DMI during the last 3 wk prepartum and first 3 wk postpartum $(P<0.006 ; \mathrm{r}=0.39)$. Mashek and Grummer (2003) suggested that the rate of change in feed intake during the prepartum period might be more predictive of postpartum intake than the absolute DMI. According to this explanation, in the report by Douglas et al. (2006) feed restriction per se was not the reason for the improved intake postpartum, but rather, the pattern of changes, which was different among feedrestricted cows and cows fed ad libitum. In our study, although lower intake was observed in both fat-supplemented groups than in the control and PGLY groups, no differences among groups were observed in the pattern of changes in DMI as calving approached (Figure 1). However, the differences in DMI between groups were not achieved by feed restriction management because the cows in all groups were fed ad libitum. Moreover, feed restriction is a different model, which might have caused the physiological changes responsible for improved intake postpartum, and this could not have been achieved with conventional management, as was performed in our study.

Milk production was higher in both fat-supplemented groups than in the control and PGLY groups, as was reported by others (Grum et al., 1996; Moallem et al., 1999). Lower protein percentages were observed in both fat-supplemented groups as compared with the control group, and similar results were observed in other reports (Grum et al., 1996; Moallem et al., 1999). In some reports the decrease in protein percentage was attributable to the decrease in DMI, which caused a decrease in protein intake. However, in the present study, although the postpartum DMI in the PrFA group was higher than in the control group, the protein percentage was lower. Casper and Schingoethe (1989) reported a lower protein percentage and lower amino acid uptake by the mammary gland in cows supplemented with fat as compared with control cows. Because of the role of somatotropin in AA uptake, Casper and Schingoethe (1989) proposed a different mechanism: dietary added fat inhibits somatotropin release from the anterior pituitary, thereby reducing mammary gland uptake of AA and consequently depressing the milk protein percentage. This proposed mechanism might explain our findings.

\section{$B W$ and BCS}

An increase of $25 \mathrm{~kg}$ of BW was observed from 28 to $1 \mathrm{~d}$ before parturition in all groups. This could partly be attributable to conceptus growth during the closeup dry period, which was estimated as 35 to $40 \mathrm{~kg}$ during the whole dry period (NRC, 2001). An increase of 0.25 units of BCS was observed, which also reflected tissue accumulation, with no differences among groups. Douglas et al. $(2004,2006)$ reported a decrease in BCS as calving approached that was concomitant with a decrease in DMI. In the current study, the rate of decreasing DMI was moderate, and this might be the 
reason for gaining $\mathrm{BW}$ and $\mathrm{BCS}$ during late pregnancy in all groups.

\section{Plasma Metabolites}

The earlier increase in plasma NEFA concentrations prepartum in cows fed both fat supplements might be due to the decrease in DMI, which caused earlier mobilization of body reserves. The results in Figure 4 indicate that the increase in NEFA concentrations began approximately $1 \mathrm{wk}$ earlier in the fat-supplemented groups than in the control and PGLY groups. In the report of Douglas et al. (2006), the cows that were feed restricted prepartum demonstrated lower plasma NEFA concentrations postpartum than cows fed ad libitum, which was attributable to the greater DMI postpartum in that group. However, in our study postpartum intake during the first 21 DIM of both fat-supplemented groups remained lower than that in the control group; therefore, we did not observe lower NEFA concentrations in these groups than in the control group.

The typical decrease in plasma insulin concentrations toward calving was observed in all treatment groups and is consistent with a previous report (Ingvartsen and Andersen, 2000). The decrease in concentrations of insulin, a lipogenic hormone, may have led to the earlier mobilization of body fat reserves, as was reflected by the earlier and higher plasma NEFA concentrations in the fat-supplemented cows as compared with cows in the control group. A reduction in plasma insulin concentrations in response to fat supplementation was previously reported (Choi and Palmquist, 1996; Grum et al., 1996; Benson and Reynolds, 2001), and this was mostly concomitant with a reduction in DMI. In the current study, there was a dramatic decrease in plasma insulin concentrations in both fatsupplemented groups (CaLFA values were $\sim 50 \%$ of control values), which was accompanied by a relatively slight decrease in intake, as compared with the control group. Previously, lower insulin concentrations in fatsupplemented cows were attributable to lower glucose and propionate availability, which are stimulatory to insulin (Benson and Reynolds, 2001). The peripartum glucose concentrations in the fat-supplemented cows in the current study were not significantly different than that in the control group and do not support this assumption. Moreover, in a study by Gaynor et al. (1994), the DMI of fat-supplemented cows decreased, with no decrease in plasma insulin concentrations. The role of insulin in feed intake is not clear, and in nonruminants there is evidence of negative feedback of insulin on intake by decreasing concentrations of neuropeptide $\mathrm{Y}$, which is a powerful intake stimulant (Schwartz et al., 1992). However, studies in ruminants demonstrated that low plasma insulin concentrations in the periparturient cow were accompanied by low feed intake (Ingvartsen and Andersen, 2000). These findings suggest that the insulin decrease in response to fat supplementation is not necessarily associated with a decrease in DMI but might be directly affected by other factors such as NEFA. Across treatments, the relationship between plasma NEFA and insulin concentrations is presented in Figure 5. Analysis of the data indicated that the power function showed the higher $\mathrm{R}^{2}$ between NEFA and insulin concentrations in plasma $(P<0.0001 ; \mathrm{r}=$ -0.39). In a study conducted in mice, Steneberg et al. (2005) reported that acute exposure to NEFA stimulated insulin secretion from pancreatic $\beta$-cells, whereas chronic exposure to NEFA impaired insulin secretion. These effects of NEFA on insulin secretion are mediated by the $\mathrm{G}$ protein-coupled receptor 40 , which is selectively expressed in $\beta$-cells and is activated by NEFA (Steneberg et al., 2005). It might be that a similar mechanism exists in ruminants and that the reduction in insulin concentrations in the periparturient cow is due to the increase in NEFA concentrations in plasma, which decreases insulin secretion from $\beta$-cells in the pancreas. According to this theory, the lower plasma insulin concentration in the fat-supplemented cows in the current study reflected a chronic exposure of the $\beta$ cells to high FA levels, which led to the lower insulin secretion. It is not clear whether the interaction between NEFA and insulin in the periparturient cow is a chain reaction or cause-and-effect reaction, and further research is needed to elucidate this relationship.

Collectively, the feed intake and plasma metabolite results of the current study indicate that fat supplementation of the diets of dairy cows starting at the close-up dry period had adverse effects on the metabolic status of the cows. Although it was not reflected in a higher incidence of peripartum morbidity in our study, feeding fat prepartum might have increased their susceptibility to metabolic disorders. However, the higher milk production and feed efficiency that were demonstrated in both fat-supplemented groups indicate that peripartum fat supplementation was beneficial to productivity, and appropriate administration could avoid a higher incidence of metabolic disorders.

Feeding PGLY as a top dressing to the TMR had no effect on prepartum feed intake and peripartum glucose, NEFA, or BHBA as compared with control group. Christensen et al. (1997) reported that the most effective means for improving the metabolic status of cows were achieved by oral drenching of PGLY compared with administering dry PGLY as a top dressing or mixed with TMR. It is important to indicate that in our study, the PGLY supplement was hand-mixed with the TMR and not administered as a bolus, as in oral drench- 


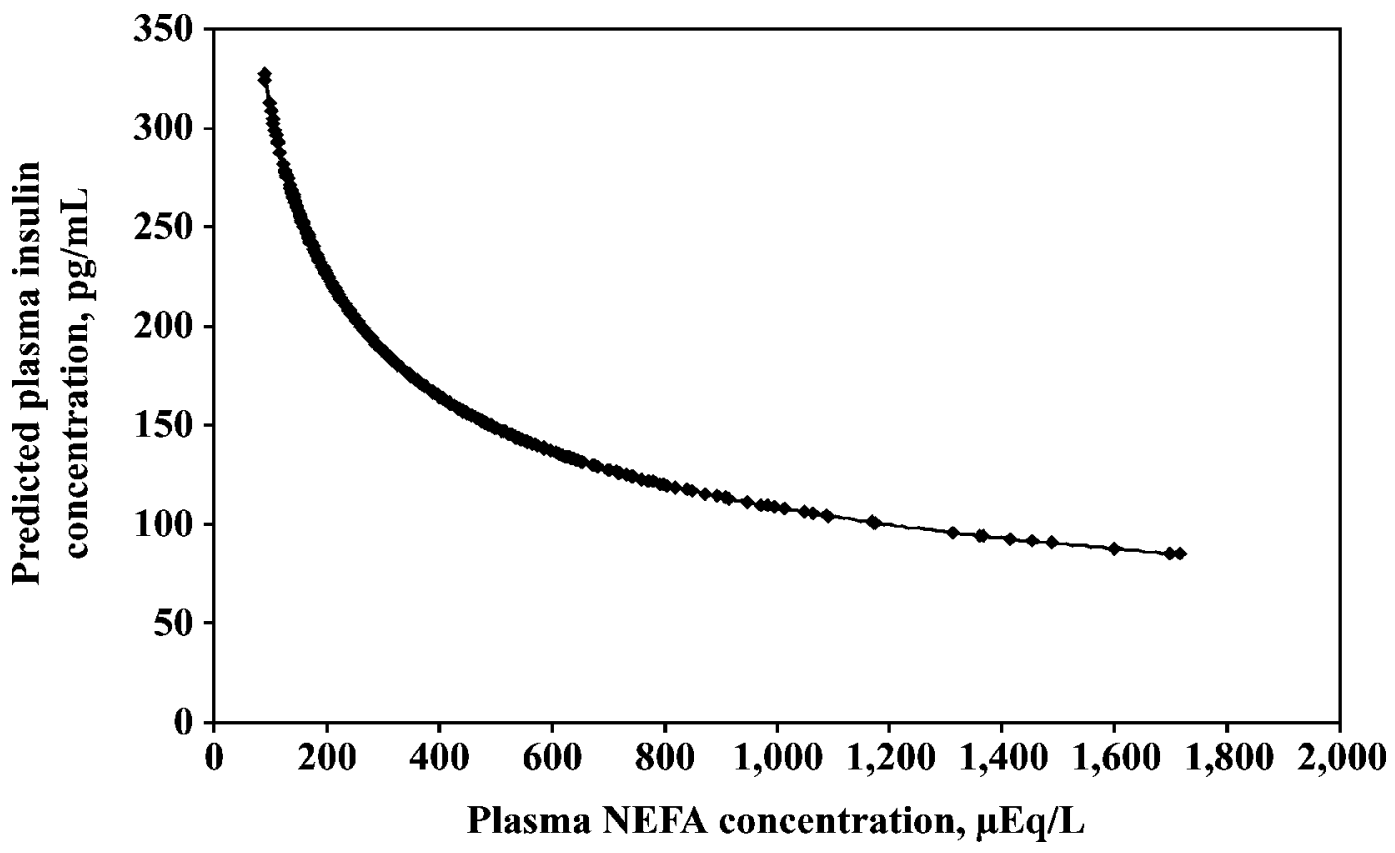

Figure 5. Relationship between NEFA and insulin concentrations in plasma of dairy cows peripartum. Predicted plasma insulin concentrations before parturition as influenced by plasma NEFA concentration according to the equation $\mathrm{Y}=2524.9 \times \mathrm{X}^{-0.4566} ; \mathrm{r}=-0.39(P<0.001)$.

ing. Although the PGLY was supplemented as a commercial product (ProGlyc 55), which included other concentrates and flavor components, prepartum DMI in the PGLY group decreased by 5\% compared with DMI in the control group $(P<0.07)$, whereas postpartum DMI in the PGLY group was $2.8 \%$ higher than in the control group $(P<0.04)$. In the current study, the PGLY was administered $5 \mathrm{~h}$ after the time of feeding, and blood was sampled $15 \mathrm{~h}$ later. As suggested by Nielsen and Ingvartsen (2004), the effect of PGLY on plasma glucose and insulin occurs shortly after consumption, and the time of blood sampling is a crucial factor in determining the effects of PGLY. The lack of effect of PGLY on blood metabolites in our study might have been caused by the long interval between PGLY administration and blood sampling (15 h).

\section{CONCLUSIONS}

Supplementing the diets of dairy cows with CaLFA or PrFA starting at the close-up dry period through 100 DIM decreased prepartum feed intake, increased plasma NEFA concentrations prepartum, increased BHBA pre- and postpartum, and decreased plasma insulin concentrations compared with cows fed a control diet or a diet supplemented with dry PGLY. Differences in the response to rumen-protected fat containing high (CaLFA) or low (PrFA) proportions of unsaturated FA were observed in peripartum DMI and plasma NEFA and insulin concentrations prepartum; the effects of CaLFA were most pronounced in increasing NEFA and depressing plasma insulin concentrations. Fat supplementation of the diets of dairy cows starting at the close-up dry period seems to have adverse effects on the metabolic status of the cows, which might increase the prevalence of metabolic disorders. However, peripartum fat supplementation was beneficial to the productivity and feed efficiency.

\section{ACKNOWLEDGMENTS}

This research was supported by Research Grant No. US-3422-03 R from the United States-Israel Binational Agricultural Research and Development Fund (BARD). The authors gratefully acknowledge the kind donation of Megalac R by Church \& Dwight (Princeton, NJ), and Energy Booster 100 by Milk Specialties (Dundee, IL). We also thank the experimental dairy farm team at the Volcani Center (Bet Dagan, Israel) for their assistance with animal care.

\section{REFERENCES}

Agenäs, S., E. Burstedt, and K. Holtenius. 2003. Effects of feeding intensity during the dry period. 1 . Feed intake, body weight, and milk production. J. Dairy Sci. 86:870-882.

AOAC. 1990. Official Methods of Analysis. Association of Official Analytical Chemists, Arlington, VA.

Bell, A. W. 1995. Regulation of organic nutrient metabolism during transition from late pregnancy to early lactation. J. Anim. Sci. 73:2804-2819. 
Benson, J. A., and C. K. Reynolds. 2001. Effects of abomasal infusion of long-chain fatty acids on splanchnic metabolism of pancreatic and gut hormones in lactating dairy cows. J. Dairy Sci. $84: 1488-1500$.

Bremmer, D. R., L. D. Ruppert, J. H. Clark, and J. K. Drackley. 1998. Effects of chain length and unsaturation of fatty acid mixtures infused into the abomasum of lactating dairy cows. J. Dairy Sci. 81:176-188.

Casper, D. P., and D. J. Schingoethe. 1989. Model to describe and alleviate milk protein depression in early lactation dairy cows fed a high fat diet. J. Dairy Sci. 72:3327-3335.

Choi, B. R., and D. L. Palmquist. 1996. High fat diets increase plasma cholecystokinin and pancreatic polypeptide, and decrease plasma insulin and feed intake in lactating cows. J. Nutr. 126:2913-2919.

Christensen, J. O., R. R. Grummer, F. E. Rasmussen, and S. J. Bertics. 1997. Effect of method of delivery of propylene glycol on plasma metabolites of feed-restricted cattle. J. Dairy Sci. 80:563-568.

Coppock, C. E., C. H. Noller, S. A. Wolfe, C. J. Callahan, and J. S. Baker. 1972. Effect of forage-concentrate ratio in complete feeds fed ad libitum on feed intake prepartum and the occurrence of abomasal displacement in dairy cows. J. Dairy Sci. 55:783-789.

Douglas, G. N., T. R. Overton, H. G. Bateman II, and J. K. Drackley. 2004. Peripartal metabolism and production of Holstein cows fed diets supplemented with fat during the dry period. J. Dairy Sci. 87:4210-4220.

Douglas, G. N., T. R. Overton, H. G. Bateman II, H. M. Dann, and J. K. Drackley. 2006. Prepartal plane of nutrition, regardless of dietary energy source, affects periparturient metabolism and dry matter intake in Holstein cows. J. Dairy Sci. 89:2141-2157.

Drackley, J. K. 1999. Biology of dairy cows during the transition period: The final frontier? J. Dairy Sci. 82:2259-2273.

Drackley, J. K., T. H. Klusmeyer, A. M. Trusk, and J. H. Clark. 1992. Infusion of long-chain fatty acids varying in saturation and chain length into the abomasum of lactating dairy cows. J. Dairy Sci. 75:1517-1526.

Gaynor, P. J., R. A. Erdman, B. B. Teter, J. Sampugna, A. V. Capuco, D. R. Waldo, and M. Hamosh. 1994. Milk fat yield and composition during abomasal infusion of cis or trans octadecenoates in Holstein cows. J. Dairy Sci. 77:157-165.

Grum, D. E., J. K. Drackley, R. S. Younker, D. W. LaCount, and J. J. Veenhuizen. 1996. Nutrition during the dry period and hepatic lipid metabolism of periparturient dairy cows. J. Dairy Sci. 79:1850-1864.

Grummer, R. R. 1993. Etiology of lipid-related metabolic disorders in periparturient dairy cows. J. Dairy Sci. 76:3882-3896.

Grummer, R. R. 1995. Impact of changes in organic nutrient metabolism on feeding the transition dairy cow. J. Anim. Sci. 73:2820-2833.
Harvatine, K. J., and M. S. Allen. 2005. The effect of production level on feed intake, milk yield, and endocrine responses to two fatty acid supplements in lactating cows. J. Dairy Sci. 88:4018-4027.

Hayirli, A., R. R. Grummer, E. V. Nordheim, and P. M. Crump. 2002. Animal and dietary factors affecting feed intake during the prefresh transition period in Holsteins. J. Dairy Sci. 85:34303443.

Ingvartsen, K. L., and J. B. Andersen. 2000. Integration of metabolism and intake regulation: A review focusing on periparturient animals. J. Dairy Sci. 83:1573-1597.

Jenkins, T. C. 1993. Lipid metabolism in the rumen. J. Dairy Sci. 76:3851-3863.

Kunz, P. L., J. W. Blum, I. C. Hart, H. Bickel, and J. H. Landis. 1985. Effects of different energy intakes before and after calving on food intake, performance and blood hormones and metabolites in dairy cows. Anim. Prod. 40:219.

Mashek, D. G., and R. R. Grummer. 2003. Effects of long chain fatty acids on lipid and glucose metabolism in monolayer cultures of bovine hepatocytes J. Dairy Sci. 86:2390-2396.

Moallem, U., Y. Folman, A. Bor, A. Arav, and D. Sklan. 1999. Effect of calcium soaps of fatty acids and administration of somatotropin on milk production, preovulatory follicular development, and plasma and follicular fluid lipid composition in high yielding dairy cows. J. Dairy Sci. 82:2358-2368.

Moallem, U., M. Katz, H. Lehrer, L. Livshitz, and S. Yakoby. 2007. Role of peripartum dietary propylene glycol or protected fats on metabolism and early postpartum ovarian follicles. J. Dairy Sci. 90:1243-1254.

Nicholson, T., and S. A. Omer. 1983. The inhibitory effect of intestinal infusions of unsaturated long-chain fatty acids on forestomach motility of sheep. Br. J. Nutr. 50:141-149.

Nielsen, N., and K. L. Ingvartsen. 2004. Propylene glycol for dairy cows: A review of the metabolism of propylene glycol and its effects on physiological parameters, feed intake, milk production and the risk of ketosis. Anim. Feed Sci. Technol. 115:191-213.

National Research Council. 2001. Nutrient Requirements of Dairy Cattle. 7th rev. ed. Natl. Acad. Sci., Washington, DC.

Relling, A. E., and C. K. Reynolds. 2007. Feeding rumen-inert fats differing in their degree of saturation decreases intake and increases plasma concentrations of gut peptides in lactating dairy cows. J. Dairy Sci. 90:1506-1515.

SAS Institute. 2000. SAS User's Guide. Statistics, Version 8.0 Edition. SAS Inst. Inc., Cary, NC.

Schwartz, M. W., D. P. Figlewicz, D. D. Baskin, S. C. Woods, and D. Porte Jr. 1992. Insulin in the brain: A hormonal regulator of energy balance. Endocrinol. Rev. 13:387-414.

Steneberg, P., N. Rubins, R. Bartoov-Shifman, M. D. Walker, and H. Edlund. 2005. The FFA receptor GPR40 links hyperinsulinemia, hepatic steatosis, and impaired glucose homeostasis in mouse. Cell Metab. 1:245-258. 